\title{
The Shakespearean unscene: Sexual phantasies in A Midsummer Night's Dream
}

\author{
Shakespeare Lecture \\ read 12 May 2016 \\ LORNA HUTSON \\ Fellow of the Academy
}

Abstract: Post-Freudian and post-Foucauldian readings of A Midsummer Night's Dream assume that the play celebrates the freeing-up of female sexual desire from neurotic inhibitions or disciplinary norms. But this is incompatible with what we know historically about 16th-century society's investment in female chastity. This paper addresses the problem of this incompatibility by turning to Shakespeare's use of forensic or legal rhetoric. In the Roman forensic rhetoric underlying 16th-century poetics, probable arguments of guilt or innocence are 'invented' from topics of circumstance, such as the Time, Place or Manner of the deed. The mysterious Night, Wood and Moonlight of Shakespeare's play can be seen as making sexual crimes (violence, stealth, infidelity) take on the form of probability and fairy agency. The play thus brilliantly represents the stories of Theseus's notorious rapes, abandonments and perjuries as fearful 'phantasies' or imaginings experienced by Hermia and Helena. This explains how the Victorians could interpret the play as a chaste, childlike ballet, while moderns and postmoderns take it to be a play about psychological repressions working against the free play of sexual desire.

Keywords: forensic rhetoric, A Midsummer Night's Dream, Shakespeare, sexuality, proof, rape, phantasia, enargeia.

\section{I}

The popular ITV series, Midsomer Murders, has nothing but the name in common with Shakespeare's A Midsummer Night's Dream. Yet there is an odd moment in Shakespeare's play that almost seems to adumbrate the series' winning formula. Hermia, having just awakened in the woods to discover the absence of her lover, Lysander, comes upon his rival, Demetrius, and immediately suspects her lover's 
violent death. We catch Hermia and Demetrius as it were in mid-conversation, with Demetrius (who at this point loves Hermia) asking her why she's angry with him. Her reply escalates, somewhat unexpectedly, into a full-blown murder charge:

Now I but chide: but I should use thee worse, For thou (I feare) hast given me cause to curse.

If thou hast slaine Lysander, in his sleepe;

Being oreshooes in blood, plunge in the deepe, \& kill mee to.

The Sunne was not so true vnto the day,

As hee to mee. Would hee haue stollen away

From sleeping Hermia? Ile beleeue, as soone,

This whole earth may be bor'd, and that the Moone

May through the Center creepe, and so displease

Her brothers noonetide, with th' Antipodes.

It cannot be, but thou hast murdered him.

So should a murderer looke; so dead, so grimme. ${ }^{1}$

Ever the opportunist, Demetrius seductively returns the charge: 'So should the murthered look, and so should I / Pierced through the heart with your stern cruelty' (3.1.58-9). Yet his reflex Petrarchism doesn't cancel out the strange blend of anguish and playfulness in Hermia's speech. How extraordinary it is that Hermia's passionate outburst should be so formally and legally structured, that it should tether the fantastical, mock-heroic extravagance of imagining the moon's Antipodean burrowing to the apparently serious function of proving a motive to kill. Hermia is saying that it would be easier to believe in this cartoon cosmic disturbance than to believe in Lysander's abandonment of her. Demetrius must, therefore, have forcibly dragged her lover away in the darkness to murder him.

Let us examine the form of Hermia's argument. The 'chief ground'2 on which she builds her 'cause' against Demetrius is that of her belief in Lysander's faith to her: 'The Sunne was not so true vnto the day, / As hee to mee'. The analogy of the sun's truth to the day wobbles a bit, feels a bit tautological, but the powerful enjambment of the rhetorical question that follows has the ring of conviction:

\section{Would hee haue stollen away \\ From sleeping Hermia?}

What comes next, however, undermines, with its irrepressible comic fantasy, the foundations of all argument. To emphasise the firmness of the 'ground' of her belief

\footnotetext{
${ }^{1}$ A Midsummer Night's Dream 1600, prepared by Thomas L. Berger (Malone Society Reprints, 1995) Q/TLN 1034-45. See also A Midsummer Night's Dream ed. Peter Holland (1994a) 3.2.45-57. I will, throughout what follows, quote from the Malone Reprint of the 1600 Quarto, giving reference to the Quarto's Through Line Numbers (Q/TLN) but I will also, for the reader's convenience, give references to the act, scene and line of Holland's edition.

${ }^{2}$ Thomas Wilson defines the 'status' or 'issue' of a legal cause as 'the chief ground of a matter' ([1560], 1994: 122).
} 
in the impossibility of Lysander's having left her, Hermia offers the hypothesis of the very ground under her feet disappearing, bored through by a mischievous female moon which, in thrusting herself into 'Her brothers noonetide' on the other side of the earth, undoes the sun's truth to the day - which was, of course, Hermia's chosen analogical proof of Lysander's truth to her: 'The Sunne was not so true vnto the day, / As hee to mee'.

So Hermia's careful architecture of proof is self-collapsing: it's the naughty moon that makes the sun untrue to the day, just as Lysander is (as we know) untrue to her. As an audience, we are likely to pick up the general irony of her situation - the fact that Lysander no longer loves her, that he has actually abandoned her-even if we do not follow the somewhat baroque form of her argument. The new director of the Globe, Emma Rice, has rightly said that a director doesn't have to hope everyone will 'understand every single word' but rather that they 'understand every situation'. ${ }^{3}$ Yet if that were all, we might wonder why. Why, if the general irony of Hermia's situation is so apparent, should Shakespeare bother to produce this useless shell of a formal legal case, by which Hermia seems to attempt to expel the fearful image of Lysander's cool indifference (you may recall that she awoke from a dream of him smiling while a serpent devoured her heart) by forming a no less fearful image of his corpse at Demetrius' feet?

Most of us would probably say that the answer lies in what Hermia's accusation reveals about Demetrius's and her own unacknowledged feelings. From comic misprision in Shakespeare's plays (we used to say) 'true selves' emerge. When Hermia begs Demetrius to 'give' Lysander back to her, his hyperbolic dismissal-'I had rather giue his carcass to my hounds' (Q/TLN 1052, 3.2.64)_jumps out, with hallucinatory force as the revelation of a truly homicidal desire. Likewise, the fact that Hermia would rather imagine Lysander murdered by a psychopathic rival than imagine him deliberately sneaking away, suggests that her love is what René Girard called 'mimetic desire': she's more in love with the image of her self as beloved, than she is with her boyfriend. ${ }^{4}$ In the criticism and theatrical productions of the 20th and 21st centuries, Hermia's dream of the serpent then becomes irresistibly legible 'in the framework of an adolescent girl's oedipal fears ... about the opposite sex'. ${ }^{5}$ Fear of sex explains both her phallic dream and the fact that even in the woods, beyond the reach of the Athenian law, she refuses to let Lysander sleep with her (Q/TLN 686, 2.2.50). ${ }^{6}$

What I have just outlined is the standard, widespread and still more or less unchallenged post-Freudian understanding of the 'shaping phantasies' of $A$ Midsummer

\footnotetext{
${ }^{3}$ Emma Rice, Daily Telegraph, 12 February 2016.

${ }^{4}$ See René Girard (1979).

${ }^{5}$ Norman Holland, (1996: 65).

${ }^{6}$ Elliot Krieger (1996: 39-40).
} 
Night's Dream (Q/TLN 1741, 5.1.5). Admittedly, critics are now, as early-20th-century Freudians were not, ready to see the erotic energies of the play as 'not heterosexual, not homosexual, not bisexual, but pansexual'. 'The turn from a 20th-century Freudian normalising towards a 21st, post-Foucauldian emphasis on the play's freer, unchoreographed sexual pleasures, however, is worth some further investigation.

Twentieth-century critics rejected both the romantic desire to dissolve in complete surrender to the magic of imagination, and the 19th-century stage's reduction of moonlit night and fairy-haunted wood to a series of lavish stage sets and gauzy special effects. They grasped that the fairy world was shot through with scepticism, and that the play's temporal and spatial setting — the wood and the summer's night — might be read, in anthropological, structuralist and psychoanalytic terms, as figures for inversion and transgression, the breaking of the powerful patriarchal laws and taboos. Glossed accordingly, the escalating recriminations of the lovers by night in the woods became newly legible in psychological terms, newly 'realistic'. Nineteenth-century critics and reviewers had disliked the lovers' vehemence-Henry Morley complained that the 'arguing, quarrelling and blundering' of the lovers should be 'playful and dreamlike and poetical' ${ }^{8}$ But for 20th-century anthropological and post-Freudian readings, the lovers' increasingly uninhibited aggressiveness and loathing made sense both in terms of the licentious inversions appropriate to rites of passage, and as the revelation, through dream-work, of deeper selves, of unconscious sexual feelings. So, for example, C. L. Barber's influential 1958 study of the affinities of Shakespeare's comedy with traditional seasonal festivities drew on ancient saturnalia and the festive pastimes of the Elizabethan calendar, tying these findings to Freudian psychoanalysis. Barber read holiday licence in 'the terms of Freud's analysis of wit', where 'the energy normally spent maintaining inhibition' is temporarily freed. ${ }^{9}$

Similarly Freudian, but less interested in normativity was Jan Kott's famous 1964 reading of the night and wood as the space and time of a descent into the darkness of the erotic. Kott recovered the diabolical origins of Puck and read in Titania's congress with Bottom not a humiliating enchantment but her own unspeakably bestial desires: 'sleep frees her from inhibitions', he wrote. ${ }^{10}$ Kott marvelled at Shakespeare's anticipation of the Freudian idea of repression. Shakespeare seems 'most ahead of his time', he marvelled, in finding a dramatic language for 'the violent contrast between the erotic madness liberated by the night and the censorship of the day, which orders everything to be forgotten'. ${ }^{11}$

\footnotetext{
${ }^{7}$ Bruce Smith (2003: 436).

${ }^{8}$ Henry Morley was reviewing Samuel Phelps's 1853 production at Salder's Wells. See Jay L. Halio (2003: 27).

${ }^{9}$ Cesar Lombardi Barber (1972: 9).

${ }^{10}$ Jan Kott (1964: 79, 82).

${ }^{11} \operatorname{Kott}(1964: 87)$.
} 
Peter Brook's ground-breaking Royal Shakespeare Company production of 1970 was, of course, the theatrical realisation of Kott's central suggestion of the nocturnal wood as a figure for the unconscious. By doubling Theseus and Hippolyta with Oberon and Titania, Brook implied that the conjugal rulers of Athens dreamt themselves into these uncensored alter egos, and the central episodes of the play 'became, in effect, their dream ... in which repressed desires are acted out'. ${ }^{12}$ As David Selbourne, witnessing the rehearsals, noted, a new 'sexual charge' became apparent throughout the interactions of lovers and fairies in the wood. When Oberon approached Titania with the love-juice, Selbourne wrote, his “ "squeezing” was its climax' and Titania's 'scream, one of seeming ecstasy, or orgasm'. ${ }^{13}$ What 19th-century critics had seen as the indecorous quarrelsomeness of the lovers emerged into a new relevance. Peter Brook told his actors that Hermia's refusal to sleep with Lysander in the woods was a sign of her frigidity, her timid clinging, in the dreamworld, to useless restraints and proprieties. 'Why don't they have it off together?', Selbourne recalls Brook asking. ${ }^{14}$ Selbourne's subsequent delighted account of the blossoming of 'character' in the rehearsals nicely shows how the theatrical essential (that the play should come alive and make sense to a contemporary audience) is intimately linked to Barber's and Kott's interpretation of wood and dream as figures for the release of unconscious impulses:

Now character blossomed where previously there had been only pasteboard and tedium ... it is as if the worst of their characters is now being disclosed in their enchantment. Their awakening, therefore, will now contain, suppressed within it-for us, and for them - an embarrassed recollection ... of how they had behaved when unrestrained and unanchored. That is, they are being revealed by the dream itself, or nightmare. ${ }^{15}$

Critics embraced the deep structure of this interpretation even where they hesitated over its orgiastic coarseness; so, for example, the Arden 2 editor, Harold Brooks, spent several pages of his 1979 introduction diagnosing the aberrant psychologies of the female characters, while describing the men as merely returning 'to the normality which was originally theirs' ${ }^{16}$ It might be objected that, since the 1980 s, the influence of Foucault and the subsequent development of queer theory make this discussion of the orgasmic or disciplinary Freudianism of C. L. Barber, Jan Kott, Peter Brook and Harold Brooks quite redundant. ${ }^{17}$ Yet while the Foucauldian challenge to the normalising operations of desire has been invaluable, critics and directors still find it hard to

\footnotetext{
${ }^{12}$ Halio (2003: 56); see also Helen Dawson, The Observer, 30 August, 1970 and David Selbourne (2010: 199).

${ }^{13}$ Selbourne (2010: 61).

${ }^{14}$ Selbourne (2010: 87).

${ }^{15}$ Selbourne (2010: 107).

${ }^{16}$ Harold F. Brooks (1979: cxi-xxiii).

${ }^{17}$ See, for example, Valerie Traub (2001); Jonathan Goldberg (1985: 134).
} 
resist interpreting the language of the lovers in the wood - especially the language of the women, Hermia and Helena - as other than comically revelatory of deeper, disavowed sexual feelings, of latent or unconscious selves for which the dreamwork of comedy acts as therapy. Moreover, although the contradiction is not always apparent, such sexually psychologising readings are extremely hard to reconcile with much of what we have learned from the work of social and cultural historians- I am thinking here of the work of Natalie Davis, Lyndal Roper, Laura Gowing, Patricia Crawford and Tom Laqueur, among others. ${ }^{18}$ From these historians we learn of the prevalence of a belief in the inherent disorderliness and excess of female sexual appetite, and of the overwhelming importance of female chastity. Exceptionally, Louis Montrose's foundational 1983 reading accommodated this kind of research, reading the play as a masculine disciplining of feminine disorderliness. But Montrose wasn't interested in making the play 'come alive for us today'. He wanted, rather, to show how it shaped and was shaped by a culture that was definitively lost to us. This was a culture summed up, in Keith Thomas's famous history of the double sexual standard, as one in which female chastity is seen 'as a matter of property; not ... the property of legitimate heirs, but the property of men in women'. ${ }^{19}$ Since women bear children, it was necessarily on their chastity that the honour and prosperity of their male kin depended; male chastity, though enjoined, was not similarly essential. Montrose saw the comedy's two conflict-generating plots - that of Egeus's paternal claim to dispose of the daughter he had created, and that of Titania's desire to withhold a human boy from the masculine fairy world - as manifestations of the play's rich subtext in the story of Theseus's struggle to subdue the Amazons. In general, then, Montrose read the layers of fantasy in A Midsummer Night's Dream as the ingenious crafting of complex, powerful and self-ironising myth of the superiority of male cultural production over the amoral and pre-cultural procreative magic of women's bodies. ${ }^{20}$

Montrose's reading makes it harder to sustain the series of associations that support the idea of the wood and the dreamworld as liberatory, permissive spaces in which women's deeper sexual selves are revealed. (It's notable, by the way, that critics who think of the wood as a 'festive' space tend to refer to it as the 'greenwood', though the term is never used in the play.) Moreover, some historicist accounts of the play's greenwood affinities have difficulty squaring their censoriousness towards female frigidity - ticking off Hermia for being inappropriately afraid of sex in this festive context—while simultaneously reproving Titania's sexual abandon. David

\footnotetext{
${ }^{18}$ For example, Natalie Zemon Davis (1965); Patricia Crawford (1981); Sara Mendelson \& Patricia Crawford (1998); Miranda Chaytor (1995); Laura Gowing (2003a). More recently, of course, literary critics have been interpreting $A$ Midsummer Night's Dream in the light of what such cultural historians have taught us about 16th-century understandings of menstruation and women's bodies. See, for example, Helen Hackett (2003).

${ }^{19}$ Keith Thomas (1959: 209-10).

${ }^{20}$ Louis Montrose, (1983; subsequently revised and expanded 1996: especially 109-211).
} 
Wiles persuasively argued, in 1993, for the play's having been written for the wedding of Thomas Berkeley and Elizabeth Carey in 1596. His thesis has much to recommend it, not least that the bride's father, Sir George Carey, was Shakespeare's patron, and Elizabeth Carey the recipient of Nashe's Terrors of the Night (1594), a treatise on dreams that shares with Shakespeare's play a sceptical pleasure in the 'Robin goodfellows, elves, fairies and hobgoblins of our latter age'. But Wiles' account of the play as epithalamium (that is, a poetic celebration for a marriage), though learnedly historicist in so many other ways, is anachronistically Freudian in its account of how Shakespeare's female characters symbolise aspects of the bride:

While Titania is the antithesis of the shrinking bride in A Midsummer Night's Dream, Hermia is the embodiment. She denies Lysander 'bed-room' ... Her subsequent Freudian dream of a snake demonstrates her fear of sexuality. Her maidenly modesty ... results in her losing the love of Lysander. ... In the peculiar context of a wedding night, Hermia's behaviour becomes no more acceptable than that of Titania. ${ }^{21}$

There's an odd fusion here between symbolic and naturalist readings; on the one hand, Titania and Hermia are both taken to be symbolic of the real bride (Elizabeth Carey) whose chastely wedded defloration, Wiles argues, the play celebrates. On the other, they are naturalistic female characters in a plot uncritically read in the Freudian terms of sexual liberation and heterosexual 'normalcy'.

So here we have the problem: on the one hand, we know that Shakespeare's plays formed and were formed by a culture now over four hundred years old whose marital and procreative ideologies we can reconstruct in detail, but to which we do not subscribe. On the other hand, it is a tribute to Shakespeare's quite extraordinary powers that we should continue to feel drawn to finding intelligible, contemporary selves in his characters rather than be content with admiring them as exemplars of now obsolete belief systems. We still seem (and for theatre directors this point is essential) inclined to respond to Shakespeare's drama as a drama that gives an inward life to the story it tells. New Historicism's innovation in enabling us to recognise the play's ideologically specific formations within Elizabethan culture has not, it seems, given us a language in which to account for what we might call, adapting Keats, Shakespeare's ideological negative capability; his capacity to hold the mirror up to successive, competing and quite incompatible ideas of nature, especially women's nature.

${ }^{21}$ David Wiles (1993: 124). 
While I cannot pretend to know what such an analytical language would look like, I would like to offer some suggestions about the rhetorical tools Shakespeare was using to produce a dramaturgy that both offered a newly vivid sense of an imagined dramatic world - in this case, of course, the moonlit wood near Athens - and an apparently transhistorical sense of the inwardness, or unconscious feeling, of the characters. As the pun in my title, 'The Shakespearean Unscene', would suggest, I am interested in the extramimetic elements of Shakespeare's drama. ${ }^{22}$ That is, I'm interested in how we infer from characters' arguments and figures of speech all that is supposed to have taken place before the play, or beyond what we can see, in another location, or, indeed, in some hypothetical future. This inferred dimension of the play's action-the before, the meanwhile and elsewhere, and the yet to come - can be very vivid and evocative, and can also have a powerful explanatory force: very often we adduce it as evidence for the way we interpret the characters and the whole dramatic action.

The image featured on the poster for this talk (figure 1) - Luibov Popova's design for a production of Romeo and Juliet at the Moscow Chamber Theatre in 1921-is suggestive of what I'm getting at here. ${ }^{23}$ What we see in Popova's constructivist design, is not an attempt to 'represent' space or a moment in time, but a playful analysis of the visual, painterly effects that elicit our desire to interpret what we see as volume, depth and direction in a particular time, a particular light. Popova draws us into reading the differing vertical thicknesses and whorls, the juxtapositions of greens, greys and ochres, and the simulations of shadow and highlight as interior spaces, curving staircases, corridors into the offstage, the inner recesses that do not exist. The whole 'scene' emphasises Renaissance theatre's dependence on our imagining that this flatness is depth, and these shadings are hollows leading inward, beyond and elsewhere.

Popova's image suggests for me an analogy with Shakespeare's use of certain rhetorical effects which likewise fool us by creating a sense of opening out, temporally and spatially, into a larger imaginary world - the childhood, for example, of the characters, or 'another part of the wood', or, indeed, 'repressed unconscious desires'. They are techniques that invite us to conjecture about places, times, motives and ways of behaving. Shakespeare did not alight upon them at random - these techniques are a standard part of a 16th-century education on rhetoric and composition that focussed on the invention of arguments of proof. Questions about where, when and how things

\footnotetext{
${ }^{22}$ I have borrowed the term 'unscene' from Majorie Garber, " "The Rest is Silence": Ineffability and the "Unscene" in Shakespeare's Plays' (1984).

${ }^{23}$ For Popova's stage designs, see John E. Bowlt (1977: especially 78-81). Bowlt notes that Popova 'possessed the rare faculty for thinking in terms both of two dimensions and three', and though her Romeo and Juliet set was not adopted as such, it led to her extraordinary three-dimensional set for Meierkhold's The Magnanimous Cuckold in 1922 (79-80).
} 


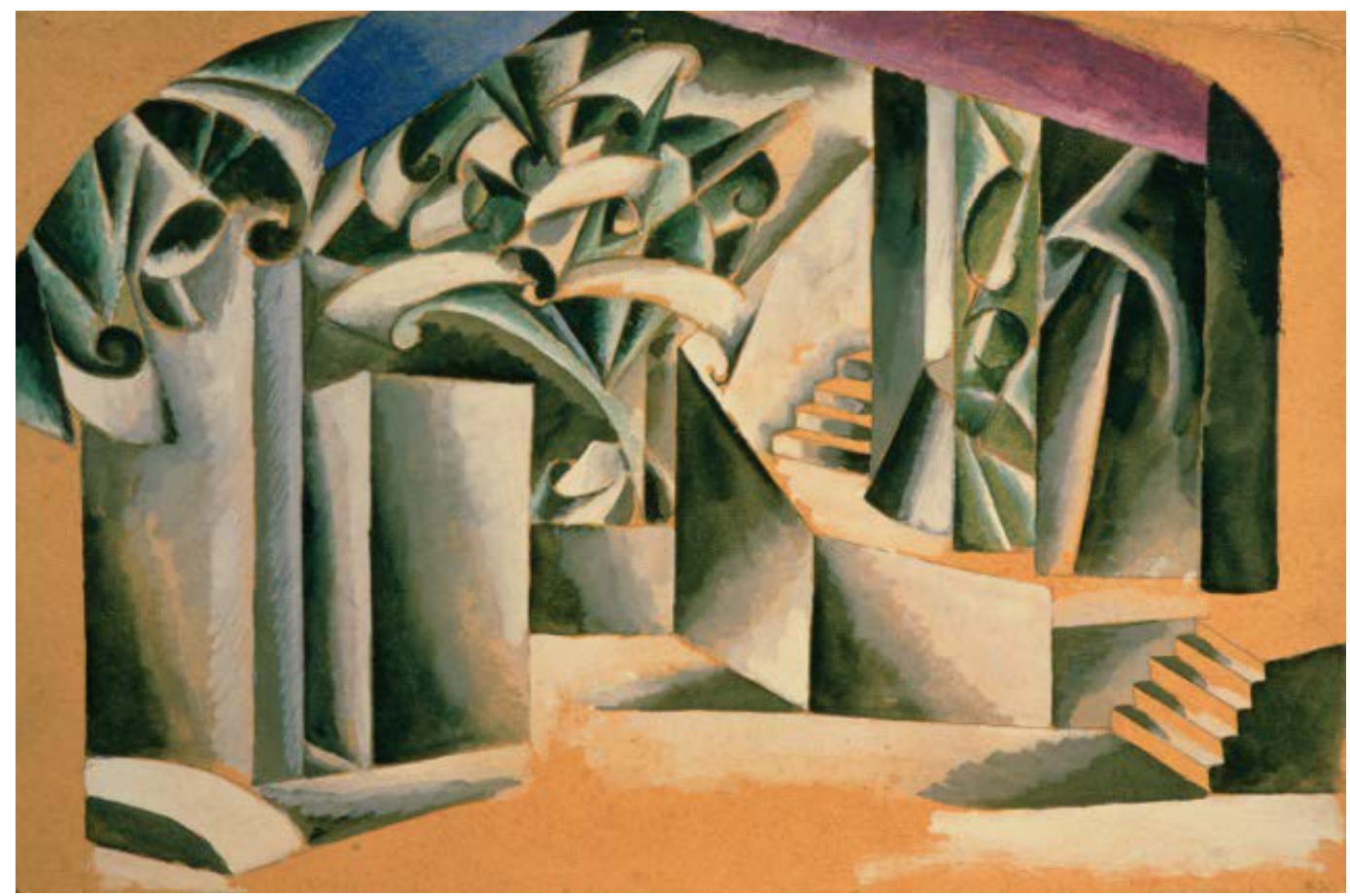

Figure 1. Luibov Popova's design for a production of Romeo and Juliet at the Moscow Chamber Theatre in 1921. (C) Bridgman

might have happened formed the core topics for inventing proof in both ancient and Renaissance poetics, though their origin was not so much in poetics as in forensic rhetoric, the rhetoric of the law courts.

For in Shakespeare's day poetic composition generally drew on the techniques of Roman forensic rhetoric. This meant that in composing narrative or drama, a writer would think of the story's setting and circumstances - the questions of where it was set, when it happened, how and why events took place - as having a more or less forensic or legal character. The narrative or dramatic situation itself would be thought of as a 'cause' or a case, for which the poet would identify a central question under dispute. This question is called in English the 'ground' or 'issue', and is divided into various kinds. The first, known as the 'issue of fact' or a 'conjectural state of the case', involves the question of whether or not an alleged deed was done. The second concedes the deed, but asks whether it was done lawfully (a legal issue) and the third, conceding the deed not lawful, asks whether it might be excused in some way (an 'issue of quality' or 'juridical issue'). ${ }^{24}$ In finding proofs to decide the issue, the student distinguishes 
between non-technical proofs, such as oaths and witnesses, and technical proofs, which require rhetorical art, and are called arguments. The most productive source of arguments in relation to the 'conjectural issue' of whether or not something actually happened are the so-called 'circumstances' or 'accidents' of the deed, which, as Quintilian lists them, comprise 'motive (causa), time, place, opportunity, means, method and the like' (causa tempus locus occasio instrumentum modus et cetera). ${ }^{25}$

If we return momentarily to my opening example of Hermia's saying to Demetrius that she 'fears' that he has given her 'cause to curse', we can then see that her cause or case against him turns on a conjectural issue (her conjecture that Demetrius has slain Lysander in his sleep) and that, as well as grounding her proof on her belief in Lysander's 'truth' or 'troth' to her, she discovers explicit and implicit proofs of time, place and manner. It seems to her most unlikely that Lysander would have left her in a clandestine manner - that is, 'stollen away' - and left her vulnerable ('sleeping') in such a place (a wood) at such a time (at night). On the other hand, the fact that Demetrius, who has a known motive (causa) in his rivalry with Lysander, is creeping around after him in a wood at night, makes the case against him seem on the face of it, quite plausible.

As I have shown in detail in my book, Circumstantial Shakespeare, these 'topics of circumstance' were foundational both to forensic rhetoric and to 16th-century composition as taught in grammar school. ${ }^{26}$ They pervade Quintilian's Institutio oratoria, a text on which Erasmus drew very heavily in writing De copia, a key grammar school text that Shakespeare would have studied at school. I am going to focus now on three of many different ways Erasmus's book taught Shakespeare to use the topics of circumstance. In book 2, chapter 8 of the De copia, the chapter on circumstances, Erasmus says they are useful:

1) for confirmatory proof and probability (ad confirmationem et probilitatem),

2) to help make an event or scene appear vividly before the eyes (ad evidentiam)

And in his chapter on vividness (evidentia, or enargeia) Erasmus implies a third use, for drama:

3) the use, in theatre, of a speech reporting something that is impossible or inconvenient to stage. ${ }^{27}$

\footnotetext{
${ }^{25}$ See Quintilian, Institutio oratoria ed. and tr. Donald Russell, 5 vols (Harvard University Press, 2001), 5.10.23. Further references to this edition will appear in the text.

${ }^{26}$ Hutson (2015).

${ }^{27}$ Erasmus: Erasmus De copia ed. Betty I. Knott, Opera Omnia (North-Holland, 1969-) ordinis I, tome 6 [hereafter ASD, I:6], I:6:202-215, 218, 230; Erasmus, Copia, Collected Works of Erasmus (University of Toronto Press, 1974-) [hereafter $C W E$ ] 24: 577-89, 591-2, 605.
} 
So how might these three uses apply to Shakespeare's creation of Wood, Night and Moonlight in A Midsummer Night's Dream? And how might the shaping of Wood, Night and Moonlight alter our conception of the 'phantasies' that Shakespeare imagines issuing from the 'seething braines' of Louers', male and female $((\mathrm{Q} / \mathrm{TLN}$ $1740,5.14)$ ?

First let us consider 'Night' and 'Wood' and 'Moonlight' as circumstantial topics of proof, 'for confirmation and probability'. 'Night' and 'the Wood' are, of course, topics of Time and Place, but 'by Moonlight' might be linked to 'Manner', the topic of how something is done. It can generally be said of the circumstance of the fact, or deed ('motive (causa), time, place, opportunity, means, method and the like') that the first of these circumstances - causa or motive - can only be proved or known by 'inventing' the others. That is, we reconstruct or imagine the nature of a deed and the motives behind it by considering time, place, opportunity, means and manner. The topics thus blur into one another. When Quintilian discusses modus or Manner ('how' something was done), he shows how arguments from Time and Place can be developed into proofs of the Manner of the deed and so of the motives of the doer. 'If, for instance', he says, 'I were to say it was done with a good intention, and so openly; or with a bad intention, and so by ambush, at night [nocte], in an isolated place [in solitudine].' (5.10.52). Quintilian here prompts the orator or poet to think about how location and time affect the way we think of the deed and determine the arguments we can use in defending or attacking it. A public killing (a tyrannicide, say) might arguably be defended as heroic, but if the manner of the killing had been clandestine (say, by means of poison) it could not be so justified. Time and Place can thus contribute to arguments of Manner, of how the thing was done, particularly with respect to proving a desire to acknowledge or to conceal responsibility. When Shakespeare evokes moonlight for us in A Midsummer Night's Dream, he takes care to remind us of its convenience for thieves. ${ }^{28}$ Cognates of the word 'to steal' (whether meaning 'to take away dishonestly', 'to abduct' or 'to move or convey noiselessly') abound. So 'by moone-light' conveys the manner by which Lysander is accused of having 'stolne' Hermia's 'phantasie' Q/TLN 53-55, 1.1.30-32); it is by moonlight, as Lysander explains, that the lovers intend to 'steal' out of Athens; what Hermia cannot believe is that Lysander would have 'stollen' from her, and so forth (Q/TLN 236; 1.1.213; Q/TLN 1039; 3.2.51).

In the arguing of a conjectural issue - the question of what might have happenedthese topics of Time, Place and Manner furnish proofs of 1) whether or not the accused person could have done the deed in that place and time (whether the time and

${ }^{28} \mathrm{Cf}$. Falstaff, in 1 Henry IV ed. A. R. Humphreys (Methuen, 1960), 1.2.25-9, 'Let us be Diana's foresters, minions of the moon ... being governed as the sea is, by our noble and chaste mistress, the moon, under whose countenance we steal'. 
place gave them the 'power') and 2) whether their being there was evidence for their will or desire to commit a crime. These are questions of 1) potestas or power and 2) voluntas, will, desire, intention or motive. ${ }^{29}$ It is quite easy to see how forensic rhetoric thus encourages a form of poetic composition in which Time, Place and Manner themselves come to seem animate and conspiratorial, as if complicit in an alleged crime. Much can be proved, Cicero says, from the nature of the place (natura ipsius locus). Is it a lonely spot, or much frequented $?^{30}$ Quintilian likewise advises asking whether the place of the alleged deed is 'frequented or deserted [frequens an desertus], near or far, convenient for the purpose or bad. ${ }^{31}$

As early as Titus Andronicus, we can see Shakespeare thinking through these topics in plotting both action and character. To persuade Tamora's sons, Chiron and Demetrius, of the ease with which they can get away with killing Bassanius and raping Lavinia, the villain Aaron runs through Cicero's formula for inquiring into 'natura ipsius locus', the nature of the place. Is there 'spatium', Cicero asked, is it 'spacious'? Is it deserted, or much frequented? Aaron's account is a textbook echo: 'The forest walks', he says, 'are wide and spacious, / And many unfrequented plots there are / Fitted by kind [natura] for rape and villany'. ${ }^{32}$ And textbook-like, too, Aaron produces the antithesis ('convenient for the purpose, or bad') by distinguishing the royal palace's inconvenience for rape, being 'full of tongues, of eyes, and ears', from the opportunity of the woods 'ruthless, dreadful, deaf and dull' (1.1.627-8).

There can be no doubt that in Titus Shakespeare was thinking of the night and the wood as topics of time, place and opportunity which help to prove the power of rape and murder, but he uses an older dramatic technique, the villain Aaron's own Vice-like declaration - to prove voluntas, or intention. Something subtler happens to voluntas - desire or intention-in A Midsummer Night's Dream. Implicit in the forensic tradition is a tendency to animate the circumstances themselves - it is the woods, as Aaron says, that are 'ruthless', the woods that are 'deaf'. We know that Shakespeare was drawn to the imaginative potential of this mode of forensic inquiry, to the way it lends a kind of personality to the agency of time and place. In his poem, Lucrece, written in 1594, his heroine personifies and accuses the circumstances of Night, Time and Opportunity of being accomplices to Tarquin, her rapist. Night, Time and Opportunity acquire criminal histories, desire, intentionalities - this is not allegorical personification, but a kind of analytical play with the elements that produce characterisation. In A Midsummer Night's Dream, it is, then, the Wood, the

\footnotetext{
${ }^{29}$ See, for example, Wilson, Art of Rhetoric [1560: 125]: 'Places of Confirmation, to Prove Things by Conjecture: 1 . Will to do evil. 2. Power to do Evil'. I am grateful to Kathy Eden for bringing to my attention the importance of the voluntas/potestas distinction, and Wilson's use of it.

${ }^{30}$ Cicero (1949: 1.26.38).

${ }^{31}$ Quint, Inst., 5.10.37.

${ }^{32}$ Titus Andronicus ed. Jonathan Bate (Arden, 2002), 1.1.614-6. Further references in the text are to this to this edition.
} 
Night and especially Moonlight that seem animate and complicit in imagined sexual crimes. Wood, Night and Moonlight - themselves the products of a poetic language of proof - are the elements shape the sexual fears and fantasies of the play.

No one, of course, is raped in A Midsummer Night's Dream. Indeed, many critics have commented on the curiously disposable feel of the lovers' plot, premised as it is on fears of nocturnal abandonments, infidelities, rapes and murders that do not actually take place. In addition, as Mary Ellen Lamb has shown, the invocation of fairy agency ('being taken with the fairies') was, in popular culture, a recognised way of veiling the human shame, the inadmissible human narratives behind traumatised signs of sexual violence, abandoned infants and illegitimate births, as well as lesser shames (such as falling down when you expect to sit on a stool). ${ }^{33}$ In Shakespeare's play, it seems, the supernatural agents traditionally called into being as cover stories for various kinds of shame and sexual transgression - that is, fairies and elves - are partly characters and partly complicit with the circumstances of time, place and opportunity (Night, Wood and Moonlight), as quasi-animate proofs of human power and willingness to transgress, and corresponding proofs of human fears of humiliation. In addition to the already-mentioned association of moonlight and theft, it's clear that Shakespeare's conception of Titania as Queen of Fairies also allows her to personify, in a series of carefully plotted allusions to moonlight and dew, the stealth of sexual pleasure. So Oberon has 'stollen away' from fairy land to make love to Phillida and Theseus is led by moonlight to ravish Perigouna, etc. (Q/TLN 55, 236, $431 ; 1.1 .32,213 ; 2.165)$.

Our second use for the circumstances was in contributing to enargeia or evidentia, a vivid, quasi-hallucinatory imagining. Quintilian shows circumstances to be essential for what he calls 'phantasiai' (Inst., 6.2.29) or what Shakespeare's Theseus calls 'shaping phantasies' (Q/TLN 1741; 5.1.5). Quintilian says the orator should actually cultivate his capacity for fantasising, so that, when engaged in pleading a criminal case before a judge, he should then be able to run through 'all the circumstances' (omnia quae in re praesenti accidisse) that might have accompanied a crime, to recreate the scene as if it were taking place before the eyes (Quintilian, Inst., 6.2.31-32). Here circumstances are not so much proofs of human intention, but vivid details (a rustling sound, or a cry, the shadow of the assailant, the flash of a blade) from which we imagine a whole scene. Shakespeare clearly knew this theory of circumstances. His 1594 poem, Lucrece, has the heroine echo Quintilian's language and ideas when, on contemplating a painting of Troy, she is impressed by the 'imaginary work' of the painter who elicits the viewer's impression of Achilles by making the vivid detail of his spear stand for the man himself:

\footnotetext{
${ }^{33}$ Mary Ellen Lamb (2000).
} 
for Achil'les image stood his spear,

Gripped in an armèd hand, himself behind

Was left unseen, save to the eye of mind. [my italics] $]^{34}$

In the same way in A Midsummer Night's Dream, the circumstances of Time, Opportunity and Place recur not only as proof in successive accusations, but also as vivid metonymic and evocative details from which we conjure up the extramimetic dimensions of the play's world, whether belonging to the childhoods of the lovers (the 'faint Primrose beddes' full of confidences evoked by Hermia (Q/TLN 238; 1.1.215), Helena's famous portrait of the two girls sharing a cushion, bent over one sampler) or to the wider fairy-governed world (the proud, pelting rivers, the putrefying corn and carrion-fed crows described by Titania) or to Hippolyta's lyrical reminiscence of hearing hounds of Sparta with Hercules and Cadmus.

This mention of the extramimetic dimensions of a play's world brings me to the third use of circumstances: the 'reporting' onstage of events supposed to have happened offstage in another time or place or in someone's imagination or dream. So-called 'reporting' derives from the practice, in classical and neoclassical drama, of introducing the plot by way of dialogue and by having a messenger, or nuntius, describe events taking place before or beyond the action. It gave rise to a range of important experimental innovations in English non-neoclassical drama in the 1590s. Native English dramatic forms (morality plays) had no techniques for conveying 'offstage action and extramimetic locations'. ${ }^{35} \mathrm{By}$ contrast, the neoclassical restriction of stage action to a single time and place helped the theatre of the 1590s to develop such techniques. Much had to be excluded from the mis-en-scène - the interiors of houses could not be shown; actions taking place elsewhere had to be 'reported' (that is, imaginatively conjectured) in vivid speeches; the histories of old injuries, rivalries and friendships that set the scene for the present action had to be conveyed and made to seem 'probable' or believable in argument and dialogue. So the tighter confinement of the action of neoclassical drama offered greater opportunity for the use of rhetorical techniques to stimulate the audience's imagination as well as introducing scepticism about imagination's effects and the reliability of witnessing.

In his chapter on enargeia or vividness, Erasmus singles out the narratives of messengers in tragedies as especially rich in the power to make images appear before the mind's eye, because they present what is impossible to stage. ${ }^{36}$ The vivid description of these speeches, he notes, 'consists in an explication of circumstances' (circumstantiarum), especially those which bring the incident most before our eyes (earum

\footnotetext{
${ }^{34}$ Shakespeare (2002: 318, lines 1424-6).

${ }^{35}$ Charles Whitworth (1977: 58).

${ }^{36}$ Erasmus, Copia, CWE, 24.578-9.
} 
praesertim quae rem oculis maximè subijciunt'. ${ }^{37}$ In 1576, Ludovico Castelvetro produced a detailed taxonomy of ways to bring the complexity of all that cannot be staged before the minds of the audience: this included the 'web of incidents' leading up to the present; actions taking place at some distance from the scene, and actions made known by supernatural means (dreams or apparitions). ${ }^{38}$ Shakespeare's rewritings of earlier plays show his interest in these new techniques: he frequently rewrote staged actions as what I am calling 'unscenes' - that is, hints, recollections, dreams, descriptions of events elsewhere. And while Anglophone critics have assumed 'reporting' to be inferior to 'staging', this assumption does not bear close scrutiny. Puck, for example, threatens Quince and company, in 3.1, that he will follow them in the shapes of hound, hog and headless bear and then exits. But when he delivers a classical 'report' of the scene to Oberon, he offers a Virgilian epic simile of the mechanicals, like russet-headed choughs, sweeping the sky in panic. He then picks out the details of briers and thorns snatching at their hats and sleeves as they flee. In the slippage or disjunction between his threatening exit and his subsequent report of it to Oberon lies a characteristically Shakespearean effect: a quality that Erasmus might have included among poetic elements that are impossible to stage. In the slippage between Puck's exit and his report, in other words, we experience the sceptical indeterminacy of the fairy world itself, the way we both believe in Puck and yet attribute his metamorphoses to the mechanicals' distracted, terrified imaginations.

\section{III}

So we have 'circumstances' of time, place and manner used for confirmation and proof, we also have circumstances as details bringing scenes vividly before our mind's eye, and we have those acts of mental scene-making as 'reports' of things impossible to stage. How do all these techniques help to create the shaping sexual fantasies of $A$ Midsummer Night's Dream? It is often said the play does not have a source-story, but critics have, more recently, been pointing to the way in which the story is shadowed by tragic and violent events in the life of Theseus. These were known from Seneca's tragedy, Hippolytus, for example, or Ovid's letters from Theseus's abandoned women, or Plutarch's Life of Theseus. ${ }^{39}$ I want to suggest that, as enargeia was, in ancient theatre, a legal concept (the vivid reconstruction of the scene of a crime), so A Midsummer Night's Dream is structured around hypothetical reconstructions of Theseus's

\footnotetext{
${ }^{37}$ D. Erasmi Roterodami de Duplici copia verborum ac rerum commentarii duo (London: Henry Middleton, 1573), fol. 122. Knott's translation, $C W E, 24.579$, lines 9-11, omits the metaphor of 'bringing before the eyes'.

${ }^{38}$ See Hutson (2015: 20-1).

${ }^{39}$ See Peter Holland (1994b); Colin Burrow (2013: 122-3).
} 
infidelities ${ }^{40}$ Behind the play's accusations of amorous thefts and changeling children (Egeus accuses Lysander, Lysander brings a charge against Demetrius, Titania and Oberon accuse each other, and so on) lies the history of Theseus's life, which the play at various points acknowledges ('Hyppolita, I woo'd thee with my sword', as Theseus says Q/TLN, 20,1.1.16). By transforming Plutarch's history of Theseus's serial rapes and abandonments into merely conjectural issues (that is, into dubious accusations that conjure up hypotheses of rape, abandonment, infidelity and illegitimate birth) the foundational history of seduction's tragic consequences turns sceptical, hypothetical and comic. It is rendered as a sequence of fearful female conjectures that turn, in various ways, on the anticipated shame of sexual abandonment, of being 'taken with the fairies'. But it is comic in that these shames do not materialise - the royal marriages take place at the end of the play, unblighted by fairy malice, unstained by illicit sex.

By this means, by animating the topics of proof (threatening Night, solitary Wood, deceiving Moonlight) and sceptically exposing the fairy world's prophylactic origins in the creative human mind, Shakespeare appears to render obsolete or invisible his own culture's profound difficulties with its investment in female sexual honour, its structural distrust of the deceptiveness of women's bodies and the testimony of women's language. In A Midsummer Night's Dream a traditional culture's investment in female sexual honour is disavowed and turned inward: it becomes 'the feminine psyche', a woman's tendency to imagine and be apprehensive of an image of herself as monstrous or shameful before the fact. Hermia and Helena each occupy, in imagination though not in fact, the position of the women Theseus is said to have raped and abandoned: Ariadne and Perigouna among others, women, whose fate has been humiliatingly reiterated through poetry and history.

Plutarch sums up Theseus's life as one of the serial 'ravishment' of women. Comparing him with Romulus, he first praises Theseus's courage in delivering Greece from tyrants and monsters, whereas Romulus slew only one tyrant, and that reluctantly. But Plutarch concludes decisively in favour of Romulus, drawing a striking contrast between the men's sexual habits. As Shakespeare would have read it in North's translation, 'touching women and ravishements', Theseus was more faulty:

for he stale away Ariadne, Antiope ... he stale away Helen in her minoritie, being nothing neere to consent to marye. Then his taking away of the daughters of the ... Amazons ... dyd geve men to suspect that his womanishnes was ... to satisfie lust.

Romulus, by contrast, arranged only one rape - that of the Sabine women - and from this violent act secured a 'most perfect bonde and league of amity' with the Sabine people, thus enlarging Rome. ${ }^{41}$

\footnotetext{
${ }^{40}$ For enargeia as a legal concept, see Kathy Eden (1986: 71-3).

${ }^{41}$ Plutarch's Lives of the Noble Grecians and Romans, Englished by Sir Thomas North [1579] (David Nutt, $\left.1895 \mathrm{a}\right)$ I.116.
} 
Shakespeare, of course, had only two years previously written a narrative poem about the founding of the Roman republic on the chastisement of a ruler's rape. In that poem he shows how difficult it is for a woman to clear herself of adultery once her marital chastity has been breached. His Lucrece knows how deploy the topics of circumstance that should prove that she had been coerced, rather than taking pleasure in the offence. But while accusing and denouncing Time, Night and Opportunity for betraying her, she repeatedly appeals to them cover her shame rather than prove her innocence. In her final speech, she acknowledges that while the circumstances amply prove her assailant's will and power, the question of her own willingness or complicity remains utterly opaque, and so she kills herself. ${ }^{42}$

So while Shakespeare saw all the potential of forensic rhetoric, with its circumstantial proofs of human motive and desire, he thought it incapable of clearing women from the shame of sexual offence. And, indeed, it seems that the more the definition of rape shifted, in early modern England, from being a crime against property to a sexual offence, the harder it became for women to sue without turning the blame on themselves. The proof now turned on the question of the woman's consent, and this was exceptionally hard to disprove, whether by bodily proof or female testimony. Pregnancy, denoting a woman's sexual pleasure, was held to disprove rape, while the plausibility of a woman's words depended on her reputation for chastity that, of course, a raped woman was already deemed to have lost. ${ }^{43}$ Moreover, 'seduction and rape were barely distinguished' in legal culture. Pressure on vulnerable young women frequently went with promises of marriage that the abandoned victims then clung to, especially if they found themselves with an illegitimate child whose father had to be declared to the parish. 'When illicit sex was in question', Laura Gowing notes, 'women conventionally responded always in the same way: that they had had sex with one man, on one occasion only, often with a promise of marriage'. ${ }^{44}$ In The Winter's Tale, the old shepherd reads some gentlewoman's 'stair-work, trunk-work, behind-doorwork' in the abandoned baby he finds, but he then passes the child off as a fairy child - 'some changeling' ${ }^{45}$ The efficacy of the 'changeling child' narrative, however, must surely have been coming under pressure, in consistory courts and quarter sessions, where mothers were being asked to reveal the names of fathers and so relieve the parish of the expense of supporting bastards. ${ }^{46}$

It is precisely because it was so difficult to prove women innocent in sexual matters that Shakespeare transformed Theseus's amours into predicaments that Hermia and

\footnotetext{
${ }^{42}$ For a detailed reading of Lucrece see Hutson (2015: 86-96).

${ }^{43}$ See Laura Gowing (2003b; 2003a: 90-92).

${ }^{44}$ Gowing (2003b: 322).

${ }^{45}$ Shakespeare, The Winter's Tale (Orgel 1996: 114, 3.3.70-3).

${ }^{46}$ See Lamb (2000: 284); Gowing (2003a: 323).
} 
Helena merely imagine experiencing at the hands of Demetrius and Lysander. North's use of the verb 'steal' for rape - 'he stale away Ariadne, Antiopa'-is echoed in Egeus's charge that Lysander has 'stolne the impression' of Hermia's 'phantasie' by 'moonelight'. (Q/TLN 53-5; 1.1.30, 32). But the crucial distinction turns on the very precise way in which Shakespeare has inflected the charge of erotic 'stealing' in such a way as to connote something more intimate, yet less explicitly sexual than Theseus's 'stealing away' of women. Earlier Italian comedies would lead audiences to expect an accusation of the 'stealing' of Hermia's virginity, not of the impression of her 'fantasy'. For example, in the English translation of La Spiritata (The Bugbeares), we're told that the young man has 'plighted / his faith \& trouthe' to his secret lover and '\& ther he her wedded / \& bedded very closely'. ${ }^{47}$ This is quite standard in earlier comic plots. Shakespeare's innovation is complex in its effects. The woman's active, imaginative participation is now essential to the rape or 'taking away' since what the man steals is her 'phantasie'-but what is left ambiguous is the relation of 'phantasie' to sexual consummation.

As we've seen, Lysander identifies the modus or Manner of the lovers' stealing out of Athens' gates with the rising of the moon, 'a time that louers flights doth still conceale' (Q/TLN 231-6, 1.1.208-13). Once lost in the wood, Lysander urges the claim of his 'oath' to get Hermia to sleep with him. Here the reminiscences of Theseus's escapades kick in. Theseus swore his faith to both Perigouna, to Ariadne, and then cast them off, each pregnant with his child. ${ }^{48}$ But why, you might ask, would it matter for a betrothed couple, like Hermia and Lysander, to have sex? It would matter, because the 'betrothal' is a knot tied by what John Kerrigan has called 'binding language' - the language of oaths and vows. ${ }^{49}$ And some people in Shakespeare's audience would know that the Spartan conqueror of Athens, Lysander (d.395 BC), was famous for making oaths he intended to break. ${ }^{50}$ It is the likelihood of Lysander's faithlessness, the likelihood informing Hermia's fear, that Puck's mistake with the magic flower comically realises, in conjectural, prophylactic form.

Thus, the scene of Hermia's solitary awakening in the wood is haunted by a reminiscence of Ariadne in Ovid's Heroides, waking, by moonlight, to find the place empty where Theseus had slept, and herself terrifyingly alone, a prey to wild beasts. ${ }^{51} \mathrm{We}$ have seen how 20th-century criticism reads both Lysander's abandonment and Hermia's dream of the serpent that 'eate my hearte away' while Lysander 'sate smiling'

\footnotetext{
${ }^{47}$ The Bugbears, 1.2.37-9 (Warwick Bond 1911: 90).

${ }^{48}$ Plutarch, 'Life of Theseus' ([1579], 1895b: p. 36).

${ }^{49}$ See John Kerrigan (2016).

${ }^{50}$ Plutarch records the saying that Lysander was 'indifferent to the obligations of an oath', and that he advocated 'cheating boys with dice, and men with oaths'. See Plutarch's 'Life of Lysander' (2001: I.588-9).

${ }^{51}$ Ovid, Heroides and Amores (1977a: X.7-15). The time, says Ariadne, was early dawn; she woke and, stretching out her arms to find her lover, discovered the bed empty. Fear cast away sleep: she leapt up, terrified.
} 
as signs of her frigidity, the first a punishment, the second a phallic revelation of her fears (Q/TLN 789-794; 3.1.151-6). But the dream recalls an Aesopian fable that occurred in a textbook Shakespeare was known to have read at school. It is the story of a farmer who took pity on a snake, and cherished it in his breast, only to have the snake wound him mortally in the heart (other versions of the fable omit this detail). ${ }^{52}$ As such, Hermia's dream signifies fear not of sex, but fear of Lysander's highly probable betrayal of his vow. She fears becoming, like Ariadne, the victim of Theseus's 'perjury and unjust flight', as Shakespeare elsewhere puts it. ${ }^{53}$ Unlike Ariadne, however, who is variously supposed, as Plutarch reports, to have 'honge her selfe for sorowe' or to have 'dyed ... in labour' of her unborn child, this abandoned heroine remains virginal, unpregnant: Lysander's post-sex infidelity remains conjectural, his smiling indifference is just her fearful imagination..$^{54}$

Thus the production of the fearful female imagination (a woman's 'phantasy') becomes key to the comedy. This is not because a woman is more easily frightened than a man, but because, in various ways, women bear the culture's burden of shame for the faiths broken for the sake of sexual enjoyment (illegitimate childbirth, the name of whore), so their fear is more culturally valuable. Shakespeare's play, I am suggesting, actively contributes to the process by which the culture's location of sexual honour in women comes to seem internal to women, a matter of inherent modesty, an imaginative, apprehensive sensitivity. So when Bottom's very first concern, in the rehearsal of Pyramus and Thisbe, turns on what will frighten the ladies, the joke lies in what these dramaturges fail to grasp about the positive imaginative potential of fear, particularly women's fear. In the devices to present Wall, Moonshine and Lion, we see the failure to grasp their function, within Ovid's plot, as circumstances of time, place and manner that help prove human motive and feeling. In Ovid, for example, Pyramus finds Thisbe's mauled scarf, and he blames himself for bidding her come first 'by night into this place full of fear' (in loca plena metus ... nocte). ${ }^{55}$ When Quince announces that 'here' is 'a maruailes conuenient place for our rehearsall' (Q/TNA 802-3; 3.1.2-3) he is, essentially, moving them into a loca plena metus, a place full of fear, a place

\footnotetext{
${ }^{52}$ T. W. Baldwin (1944: I.615ff), follows H. R. D. Anders, who persuasively identifies numerous fables in Shakespeare as having derived their specific forms from Joachim Camerarius's Fabellae Aesopicae (1573). Having analysed the parallels between Camerarius's Aesop and Aesopian allusions in numerous Shakespeare plays, Baldwin concludes, 'Shakespeare evidently got his Aesop in Stratford grammar school about 1573 or 1574, either in the Latin translation of Camerarius in some edition by or before 1573, or in some form closely akin to it' (639). With respect to the fable of the farmer and the snake, what is distinct about Camerarius's version (as opposed to Caxton's or Bulloker's) is that the farmer does not merely warm the snake by the fire, but cherishes the snake in his bosom ('fouere sinu') and that the snake does not merely injure him, but wounds him mortally ('letale vulnus inflixit') (617).

${ }^{53}$ Julia describes herself performing the part of Ariadne after Theseus has deserted her. See Shakespeare, Two Gentlemen of Verona (Carroll, 2004: 262, 4.4.166).

${ }^{54}$ Plutarch ([1579],1895b: 46).

${ }^{55}$ Ovid Metamorphoses (1977b; IV.111, vol. I, 184-5).
} 
which will prove how effective fear is in stimulating the imagination. He and his fellows will run from Bottom, in such 'distracted fear', as Puck says, that they conjure up the hobgoblin himself. But they miss, in their dramatic realisation of Ovid's story, the Ovidian and Shakespearean capacity to imbue the circumstances of place and time with human motives and passions. In personating Wall, Moonshine and Lion, rather than in plotting them as the circumstances of the lovers' fearful conjectures about one another's fates, Quince's troupe highlight, by brilliant comic contrast, how Shakespeare himself has turned the Wood, Night and Moonlight into the co-ordinates of his human characters' fearful imaginings. ${ }^{56}$

Shakespeare's play is profoundly interested in what Snout refers to as making 'ladies afeard'. It is interested, that is to say, in the potentially prophylactic and disciplinary power of the fearful female imagination. Critics exploring parallels between $A$ Midsummer Night's Dream and the epithalamia of Spenser, Donne and others note that epithalamia characteristically banish the evil world of Puck and of the elves and fairies just before the wedding night ('Ne let the Poucke, nor other evil sprights ... Fray us with things that be not', says Spenser). ${ }^{57}$ It's often also noted that in Shakespeare's hands, the world of fairy ceases to be diabolic and becomes more fanciful. ${ }^{58}$ Both these observations fit with a dramaturgical project of realising the trauma, violence and sexual shame associated with the wickedness of the fairy world in the sceptical and comic form of merely imaginary fears, feminine responses to the circumstances of time and place, the nocturnal wood. Indeed, the interest that 20th-century critics have taken in the aberrant psychologies of Hermia and Helena (Harold Brooks's Arden edition, as we have seen, spends several pages analysing them) is testimony to the success with which Shakespeare has translated the sexual double standard into something legible to us as feminine pathology. I will turn, in conclusion, from the numerous psychoanalytic studies of Hermia's phallic dream and Hermia's sexual inhibitions, to Helena, 'a type of personality', as Brooks commented in 1979, 'particularly obnoxious to men'. If the 20th-century Hermia is frigid, the 20th-century Helena is a masochist: beginning the play as 'very feminine' she goes on actively to solicit sexual violence, 'demean[ing] herself, spaniel-fashion' to Demetrius. ${ }^{59}$

The moon vanishes in the long second scene of Act 3, when the lovers plunge into darkness and loathing. Titania and Bottom are possibly visible or possibly not. The dominant 20th-century view of this scene as one of libidinal and psychic release has increasingly led to critics conjecturing uneasily the nature of the sex we are to imagine

\footnotetext{
${ }^{56}$ Thisbe sees the lioness 'by the rays of the moon' (ad lunae radios); Pyramus sees traces (vestigia) of the beast and Thisbe's cloak coloured with blood (sanguine tinctam), Ovid, Metamorphoses (1977b: IV.99, 105, 107).

${ }^{57}$ Spenser, Epithalamion, 341-4, (Oram et al. 1989). For convincing parallels between Spenser's poem and Shakespeare's play, see Wiles (1993).

${ }^{58}$ See Minor White Latham (1930).

${ }^{59}$ Harold F. Brooks (1979: cxi, cxii, cxiii).
} 
(is it bestiality?) while directors inevitably want to expose it onstage. ${ }^{60}$ If, however, we think of the play's historical innovation as the production, not of orgasmic release, but of a gendered internalisation of sexual shame, a new identification of femininity with sexual inhibition, then it matters that it remain an unscene, a teasing, disturbing pressure on the imagination. Carefully plotted linguistic parallels between Titania and Helena throughout the play direct us, I suggest, to experience the displacement of the shame attaching to Titania's comic punishment by Oberon as Helena's quite astonishing capacity to imagine herself the victim of a similar sexual humiliation at the hands of Lysander and Demetrius.

As we listen to successive changes in Helena's language about how she is seen and sees herself, we're aware, at the same time, of changes in the metaphors of the liquid moonlight associated with Titania. As we have seen, the watery moonlight begins as a proof of stealthy manner and so a circumstance proving a guilty sexual intention. Gradually, however, it becomes associated with tearful exposure, shame and humiliation. So the veiled disgracing of Titania becomes linguistically associated with the slow transformation of Helena from a woman who thought herself 'as fair' as her companion, to one who, when men protest to her how beautiful she is, can only experience their lovemaking as a realisation of her sense of 'insufficiency', a mockery of her alleged failures in modesty.

Behind this linguistic drama, lies, once again, the story of Theseus's rapes. If Hermia is a comic Ariadne, Helena is the comic Perigouna. For Perigouna, as Plutarch tells us, sought safety from Theseus by praying to the bushes in the woods to hide her. Perigouna and Ariadne first emerge into the play as part of Oberon's accusation against Titania. How can Titania, 'for shame', Oberon asks, accuse him of infidelity with Hippolyta,

Knowing, I know thy loue to Theseus.

Didst thou not lead him through the glimmering night,

From Perigenia, whom he rauished?

And make him, with fair Eagles [Aegles], break his faith,

With Ariadne, and Antiopa? (Q/TLN 440-444; 2.1.77-80)

There's a curious asymmetry here. We expect Oberon to charge Titania with being Theseus's lover, but his words make her a circumstance of Opportunity-she is one with the glimmering moonlight that facilitated his rape of Perigouna. Femininity itself is charged with the shame of seduction: enargeia here conveys the cultural assumption that women, with their deceptive bodies and unreliable words, are the vehicles of their own sexual dishonour; they are the reasons why men break their faith.

\footnotetext{
${ }^{60}$ Andrew Sofer has argued for the importance of not staging the lovemaking between Titania and Bottom. See his interesting comments in Dark Matter: Invisibility in Drama, Theater and Performance (2013: 54): 'We cannot tell if they are making love or not making love offstage - and to observe them in the act (as some productions do) is instantly to tumble them out of quantum into classical dramaturgy.'
} 
So when Helena finds herself, Perigouna-like, mistaking the woods for her refuge, the ominously named Demetrius addresses her in a speech which ostentatiously turns the formal proofs of his potestas and voluntas - power and desire - to rape her, into proofs of her immodesty in thus courting her own rape:

You doe impeach your modestie too much,

To leaue the citie, and commit your selfe,

Into the hands of one that loues you not,

To trust the opportunitie of night,

And the ill counsell of a desert place,

With the rich worth of your virginitie. $(\mathrm{Q} / \mathrm{TLN} 583-8 ; 2.1 .214-9)$

Perigouna's prayer to the bushes becomes an impeachment of Helena's modesty, evidenced by her listening to the evil counsel of the woods and trusting that very glimmering that made the night full of opportunity for Theseus. Shakespeare blends the magical thinking that animates places and times with the forensic topics of circumstance that imbue place and time with human agency and intentionality and in so doing turns the proofs of Demetrius's power into the suggestion that Helena harbours immodest intentions, a desire to be raped.

Helena, as everyone remarks, begins the play confident of public estimation of her value, 'Through Athens, I am thought as faire as she' (Q/TLN 251; 1.1.227). She then famously makes Hermia's eyes the mirror in which she sees her own 'attractiveness' as wanting. (Q/TLN 205; 1.1.183). The glamorous mirror she seeks finds expression in Lysander's elaboration of moonlight as sexual opportunity.

To morrow night, when Phoebe doth beholde

Her siluer visage in the watry glasse,

Decking, with liquid pearle the bladed grasse

(A time that louers flights doth still conceale)

Through Athens gates, haue we deuised to steale. (Q/TNA 232-6; 1.1.208-213)

The moonlight facilitating their escape is figured as erotically confident and complacent, pleased with what her reflection confirms about the glamour she lends to covert sexual liaison. In the next act, however, as Demetrius abandons her 'darkling', Helena utters an extraordinary speech in which this same figure of the watery mirror turns into one of shameful weeping. Helena contrasts Hermia's 'attractive' eyes with her own, awash with tears of shame for having believed the 'wicked' mirror that told her her femininity was beautiful rather than monstrous:

How came her eyes so bright? Not with salt teares,

If so, my eyes are oftner washt than hers.

No, no: I am as vgly as a Bear:

For beastes that meete mee runne away, for feare ... 
What wicked and dissembling glasse, of mine

Made me compare with Hermias sphery eyne? (Q/TLN 736-42, 2.2.98-105)

Demetrius's 'You doe impeach your modestie too much' is now registered in the eye of the woman's mind as a vision of her own body as repellently immodest, monstrous. Moments later she responds to Lysander's professions of love not with gratification or sceptical laughter, but with a hurt and bewildered sense that her 'insufficiency' has always been known and is now being made into a piece of street theatre: 'Wherefore was I to this keene mockery born?' (Q/TLN 767, 2.2.129). Her brilliantly creative misconstruing is followed, in the play, by Bottom's monstrous translation, by the distracted fear of the mechanicals, and finally by Titania's registering of the moon's sorrow as she leads fulfils Oberon's punishment by leading her lover to her bower:

The Moone, methinkes, lookes with a watry eye:

And when shee weepes, weepes euery little flower,

Lamenting some enforced chastitie. (Q/TLN 984-6; 3.2.188-90)

Like Helena, the moonlight itself now weeps. The dew that mirrored the moon's seductive beauty is now the tearful lament of seduction's abandoned victims. In Oberon's vivid report, too, of the 'coronet' with which Titania garlanded Bottom's temples,

... that same deawe which sometime on the buddes

Was wont to swell, like round and orient pearles;

Stood now within the pretty flouriets eyes,

Like teares, that did their owne disgrace bewaile. (Q/TLN 1520-3; 4.1.52-5).

And once again, the dewy moonlight of sexual opportunity turns into shameful self-consciousness, expressed as penitent female weeping.

At the beginning of this lecture, I applauded Louis Montrose's New Historicist account of A Midsummer Night's Dream for showing us how Shakespeare's comedy was immersed in early modern beliefs about women and procreation. Montrose read the play as shaping a new myth of the superiority of male cultural production over the amoral and pre-cultural procreative magic of women's bodies. But Montrose's chiastic formula - that plays shaped and were shaped by early modern culture - did not help us to see how Shakespeare's dramaturgy of the 'unscene' has also worked to shape incompatible gender ideologies of successive centuries. By having his comedy's heroines vividly imagine themselves as the victims of non-existent sexual abandonments and social ostracisms, Shakespeare created a play that reshaped the evil fairies of folklore (the 'Pouke' and 'other euill sprightes' that registered society's investment in women's sexual purity) into the altogether more sceptical, privatised and prophylactic form of an individual young women's fearful fantasy. This helps to explain why 
the Victorians - with a few euphemistic lexical changes such as 'maiden heart' for Hermia's 'virgin patent' - were able to stage the Dream as sexually innocent, a chaste, child-like fairy ballet. ${ }^{61}$ But it also explains why 20th-century critics and directors, amazed at Victorian naivety, put all the 'unscene' sex back into the play and then had to invent the idea of women's sexual inhibitions, repressions and other neuroses to explain why they were so busy fending it off.

\section{Acknowledgements}

I am grateful to James Rivington and Penny Collins of the British Academy for the invitation to give this lecture, and I join the many who are indebted to Mrs Frida Mond's original endowment. Thanks, too, to John Kerrigan for chairing the event and to those in the Sam Wanamaker Theatre who darkling listened, and asked such cogent questions afterwards.

\section{REFERENCES}

Baldwin, T. W. (1944), William Shakspere's Small Latine \& Lesse Greeke, 2 vols, (Urbana, IL, University of Illinois Press).

Barber, Cesar Lombardi (1972), Shakespeare's Festive Comedy: A Study of Dramatic Form and its Relation to Social Custom (Princeton, NJ, Princeton University Press).

Bate Jonathan (ed.) (2002), Titus Andronicus (London, Arden).

Berger, Thomas L. (ed.) (1995), A Midsummer Night's Dream 1600 (Oxford, Malone Society Reprints).

Bowlt, John E. (1977), 'Constructivism and Russian Stage Design', Performing Arts Journal, 1(3): 62-84. http://dx.doi.org/10.2307/3245250

Brooks, Harold F. (1979), A Midsummer Night's Dream (London, Methuen).

Burrow, Colin (2013), Shakespeare and Classical Antiquity (Oxford, Oxford University Press).

Chaytor, Miranda (1995), 'Husband[ry]: Narratives of Rape in the Seventeenth Century', Gender and History, 4: 378-407. http://dx.doi.org/10.1111/j.1468-0424.1995.tb00033.x

Cicero (1949), De inventione tr. H. M. Hubbell (Cambridge, MA, Harvard University Press).

Crawford, Patricia (1981), 'Attitudes to Menstruation in Seventeenth Century England', Past and Present, 91: 47-73. http://dx.doi.org/10.1093/past/91.1.47

Eden, Kathy (1986), Poetic and Legal Fiction in the Aristotelian Tradition (Princeton, NJ, Princeton University Press). http://dx.doi.org/10.1515/9781400858323

Eden, Kathy (forthcoming), 'Forensic Rhetoric and Humanist Education', in Lorna Hutson (ed), The Oxford Handbook of English Law and Literature, 1500-1700 Oxford, Oxford University Press).

Erasmus (1969-), De copia, in Betty I. Knott (ed.), Opera Omnia (Amsterdam, North-Holland) ordinis I, tome 6.

Erasmus (1974), Copia, Collected Works of Erasmus (Toronto, University of Toronto Press).

\footnotetext{
${ }^{61}$ Gary J. Williams noted that, as the 19th century progressed, theatre managers 'take increasing pains to be wholesome . . . in 1840, Hermia was allowed to speak of her "virgin patent" (I.i.89), but for Daly and Tree near the close of the century, she spoke of her "maiden heart", (1977: 6). See also Halio (2003: 22-30).
} 
Garber, Marjorie (1984), “ "The Rest is Silence”: Ineffability and the "Unscene” in Shakespeare's Plays', in Peter S. Hawkins \& Anne Howard Schotter (eds), Ineffability: Naming the Unnameable from Dante to Beckett (New York, AMS Press), 35-50.

Girard, René (1979), 'Myth and Ritual in A Midsummer Night's Dream', in Josue Harari (ed.), Textual Strategies (Ithaca, NY, Cornell University Press), 189-212.

Goldberg, Jonathan (1985), 'Shakespearean Inscriptions: The Voicing of Power', in Patricia Parker \& Geoffrey Hartman (eds), Shakespeare and the Question of Theory (London, Taylor \& Francis), 55-78.

Gowing, Laura (2003a), Common Bodies: Women, Touch and Power in Seventeenth Century England (New Haven, CT, Yale University Press).

Gowing, Laura (2003b), 'Bodies and Stories', in Margaret Mikesell \& Adele Seeff (eds), Culture and Change: Attending to Early Modern Women (Newark, DE, University of Delaware Press), 317-332.

Hackett, Helen (2003), 'A Midsummer Night's Dream', in A Companion to Shakespeare's Works: Volume III The Comedies Richard Dutton \& Jean E. Howard (eds), (Oxford, Blackwell), 338-357.

Halio, Jay L. (2003), A Midsummer Night's Dream: Shakespeare in Performance (Manchester, Manchester University Press).

Holland, Norman (1996), 'Hermia's Dream', in Richard Dutton (ed.), New Casebooks: A Midsummer Night's Dream (London, Macmillan), 61-83.

Holland, Peter (ed.) (1994a), A Midsummer Night's Dream (Oxford, Oxford University Press).

Holland, Peter (1994b), 'Theseus's Shadows in A Midsummer Night's Dream', Shakespeare Survey, 47: $139-51$.

Humphreys, A. R. (ed.) (1960), Henry IV(London, Methuen).

Hutson, Laura (2007), The Invention of Suspicion: Law and Mimesis in Shakespeare and Renaissance Drama (Oxford, Oxford University Press).

http://dx.doi.org/10.1093/acprof:oso/9780199212439.001.0001

Hutson, Lorna (2015), Circumstantial Shakespeare (Oxford, Oxford University Press). http://dx.doi.org/10.1093/acprof:oso/9780199657100.001.0001

Kerrigan, John (2016), Shakespeare's Binding Language (Oxford, Oxford University Press). http://dx.doi.org/10.1093/acprof:oso/9780198757580.001.0001

Kott, Jan (1964), Shakespeare our Contemporary tr. Boleslaw Taborski, (London, Methuen).

Krieger, Elliot (1996), 'A Midsummer Night's Dream', in Richard Dutton (ed.), A Midsummer Night's Dream: New Casebooks (London, Macmillan), 38-60.

Lamb, Mary Ellen (2000), 'Taken by the Fairies: Fairy Practices and the Production of Popular Culture', in A Midsummer Night's Dream', Shakespeare Quarterly, 51(3): 277-312. http://dx.doi.org/10.2307/2902152

Mendelson, Sara \& Crawford, Patricia (1998), Women in Early Modern England 1550-1720 (Oxford, Oxford University Press). http://dx.doi.org/10.1093/acprof:oso/9780198201243.001.0001

Montrose, Louis (1983), 'Shaping Fantasies: Figurations of Gender and Power in Elizabethan Culture', Representations, 2: 61-94. http://dx.doi.org/10.1525/rep.1983.2.1.99p0006e

Montrose, Louis (1996), The Purpose of Playing: Shakespeare and the Cultural Poetics of Elizabethan Theatre (Chicago, IL, University of Chicago Press).

Ovid (1977a), Heroides and Amores tr. Grant Showerman, rev. G. P. Goold (Cambridge, MA, Harvard University Press).

Ovid (1977b), Metamorphoses, tr. Frank Justus Miller, 2 vols, (Cambridge, MA, Harvard University Press).

Plutarch ([1579],1895a), Lives of the Noble Grecians and Romans, Englished by Sir Thomas North (London, David Nutt).

Plutarch ([1579],1895b), 'Life of Theseus', in Lives of the Noble Grecians and Romans, Englished by Sir Thomas North (London, David Nutt), 45-7. 
Plutarch (2001), 'Life of Lysander', in tr. John Dryden, Arthur Hugh Clough (ed.), 2 vols, Plutarch's Lives (New York, Random House).

Quintilian (2001), Institutio oratoria ed. and tr. Donald Russell, 5 vols, (Cambridge, MA, Harvard University Press).

Selbourne, David (2010), The Making of 'A Midsummer Night's Dream' (London, Faber and Faber).

Shakespeare, William (2004), Two Gentlemen of Verona William C. Carroll (ed., London, Thomson Learning).

Shakespeare, William (1996), The Winter's Tale Stephen Orgel (ed.), (Oxford, Oxford University Press).

Shakespeare, William (2002), Lucrece, in Colin Burrow (ed.), The Complete Sonnets and Poems (Oxford, Oxford University Press). http://dx.doi.org/10.1093/actrade/9780198184317.book.1

Skinner, Quentin (2014), Forensic Shakespeare (Oxford, Oxford University Press).

Smith, Bruce (2003), 'Studies in Sexuality', in Stanley Wells \& Lena Cowen Orlin (eds), Shakespeare: An Oxford Guide (Oxford, Oxford University Press) , 431-171.

Sofer, Andrew (2013) Dark Matter: Invisibility in Drama, Theater and Performance (Ann Arbor, MI, University of Michigan Press). http://dx.doi.org/10.3998/mpub.3186316

Spenser, Edmund (1989), Epithalamion, in The Yale Edition of the Shorter Poems of Edmund Spenser William A. Oram et al. (eds), (New Haven, CT, Yale University Press): 675-6.

Thomas, Keith (1959), 'The Double Standard', Journal of the History of Ideas, 20: 195-216. http://dx.doi.org/10.2307/2707819

Traub, Valerie (2001), 'The Renaissance of Lesbianism in Early Modern England', GLQ: A Journal of Gay and Lesbian Studies, 7(2): 245-263. http://dx.doi.org/10.1215/10642684-7-2-245

Warwick Bond, R. (1911), Early Plays from the Italian (Oxford, Clarendon Press).

White Latham, Minor (1930), The Elizabethan Fairies: The Fairies of Folklore and the Fairies of Shakespeare (New York, Columbia University Press).

Whitworth, Charles (1977), 'Reporting Offstage Events in Early Tudor Drama', in André Lascombes (ed.) Tudor Theatre: 'Let there be Covenants' (Berne, Peter Lang), 45-66.

Wiles, David (1993), Shakespeare's Almanac: A Midsummer Night's Dream, Marriage and the Elizabethan Calendar (Cambridge, D. S. Brewer).

Williams, Gary J. (1977), 'Madame Vestris': A Midsummer Night's Dream and the Web of Victorian Tradition', Theatre Survey, XVIII: 1-22. http://dx.doi.org/10.1017/S0040557400009212

Wilson, Thomas ([1560], 1994), The Art of Rhetoric, Peter Medine (ed.), (Pennsylvania, PA, Pennsylvania State Press).

Zemon Davis, Natalie (1965), 'Women on Top', in Society and Culture in Early Modern France (Cambridge, Polity Press), 12-51.

Note on the author: Lorna Hutson is Merton Professor of English Literature at Oxford. Her interests are in the rhetorical bases of Renaissance Literature, emphasising fiction's affinities with forensic rhetoric. Her most recent book, Circumstantial Shakespeare (Oxford University Press, 2015) is based on the Oxford Wells Shakespeare Lectures delivered in 2012 and her Oxford Handbook of English Law and Literature 1500-1700 is forthcoming. She currently holds a Leverhulme Major Research Fellowship for research on 16th-century Anglo-Scots literary relations. lorna.hutson@ell.ox.ac.uk 
The Shakespearean unscene: Sexual phantasies in A Midsummer Night's Dream 195

To cite the article: Lorna Hutson (2016), 'The Shakespearean unscene: Sexual phantasies in A Midsummer Night's Dream', Journal of the British Academy, 4: 169-195.

DOI $10.85871 / \mathrm{jba} / 004.169$

This article is licensed under a

Creative Commons Attribution-NonCommercial-NoDerivs 3.0 Unported License.

Journal of the British Academy (ISSN 2052-7217) is published by

The British Academy - the national academy for the humanities and social sciences.

10-11 Carlton House Terrace, London, SW1Y 5AH

www.britishacademy.ac.uk 